\title{
Novel, Stable Catholyte for Aqueous Organic Redox Flow Batteries: Symmetric Cell Study of Hydroquinones with High Accessible Capacity
}

\author{
Xian Yang ${ }^{1,2,3,+} \mathbb{D}$, Sergio Navarro Garcia ${ }^{4,+}$, Tobias Janoschka ${ }^{3}$, Dénes Kónya ${ }^{4, *}$, Martin D. Hager ${ }^{1,2} \mathbb{D}$ and \\ Ulrich S. Schubert 1,2,* \\ 1 Laboratory of Organic and Macromolecular Chemistry (IOMC), Friedrich Schiller University Jena, \\ Humboldtstrasse 10, 07743 Jena, Germany; xian.yang@jenabatteries.de (X.Y.); \\ martin.hager@uni-jena.de (M.D.H.) \\ 2 Center for Energy and Environmental Chemistry Jena (CEEC Jena), Friedrich Schiller University Jena, \\ Philosophenweg 7a, 07743 Jena, Germany \\ 3 JenaBatteries $\mathrm{GmbH}$, Otto-Schott-Strasse 15, 07745 Jena, Germany; tobias.janoschka@jenabatterie.de \\ 4 Research Centre for Natural Sciences, Magyar Tudosok Korutja 2, 1117 Budapest, Hungary; \\ sergio.navarro@ttk.hu \\ * Correspondence: konya.denes@ttk.hu (D.K.); ulrich.schubert@uni-jena.de (U.S.S.) \\ + Equal contribution.
}

check for updates

Citation: Yang, X.; Garcia, S.N.; Janoschka, T.; Kónya, D.; Hager, M.D.; Schubert, U.S. Novel, Stable

Catholyte for Aqueous Organic Redox Flow Batteries: Symmetric Cell Study of Hydroquinones with High Accessible Capacity. Molecules 2021, 26, 3823. https://doi.org/10.3390/ molecules 26133823

Academic Editor: Subashani Maniam

Received: 31 May 2021

Accepted: 19 June 2021

Published: 23 June 2021

Publisher's Note: MDPI stays neutral with regard to jurisdictional claims in published maps and institutional affiliations.

Copyright: (c) 2021 by the authors. Licensee MDPI, Basel, Switzerland. This article is an open access article distributed under the terms and conditions of the Creative Commons Attribution (CC BY) license (https:// creativecommons.org/licenses/by/ $4.0 /)$.

\begin{abstract}
Owing to their broad range of redox potential, quinones/hydroquinones can be utilized for energy storage in redox flow batteries. In terms of stability, organic catholytes are more challenging than anolytes. The two-electron transfer feature adds value when building all-quinone flow battery systems. However, the dimerization of quinones/hydroquinones usually makes it difficult to achieve a full two-electron transfer in practical redox flow battery applications. In this work, we designed and synthesized four new hydroquinone derivatives bearing morpholinomethylene and/or methyl groups in different positions on the benzene ring to probe molecular stability upon battery cycling. The redox potential of the four molecules were investigated, followed by long-term stability tests using different supporting electrolytes and cell cycling methods in a symmetric flow cell. The derivative with two unoccupied ortho positions was found highly unstable, the cell of which exhibited a capacity decay rate of $\sim 50 \%$ per day. Fully substituted hydroquinones turned out to be more stable. In particular, 2,6-dimethyl-3,5-bis(morpholinomethylene)benzene-1,4-diol (asym-O-5) displayed a capacity decay of only $0.45 \%$ /day with four-week potentiostatic cycling at $0.1 \mathrm{M}$ in $1 \mathrm{M} \mathrm{H}_{3} \mathrm{PO}_{4}$. In addition, the three fully substituted hydroquinones displayed good accessible capacity of over $82 \%$, much higher than those of conventional quinone derivatives.
\end{abstract}

Keywords: hydroquinone; catholyte; stability; symmetric cell study; redox flow batteries; energy storage

\section{Introduction}

Research on redox flow batteries (RFBs) has, in recent years, shifted from metal-based materials to organic active materials that are abundant in nature and have great potential to reduce costs by improving synthetic strategies [1,2]. Since the redox-active organic molecule tiron (4,5-dibenzoquinone-1,3-benzenedisulfonate) was initially introduced as a catholyte in RFB in 2009 [3], it has aroused extensive attention in developing novel, redox-active organic molecules with high solubility and stability for practical redox flow battery applications. To date, quite a few candidates have been investigated in RFBs [4-14], among which two organic RFB systems, the TEMP-TMA/MV (N,N,N-2,2,6,6-heptamethylpiperidinyl oxy-4-ammonium chloride/ $N, N^{\prime}$-dimethyl-4,4-bipyridinium dichloride) system and ferrocyanide/anthraquinone system, were validated and industrialized in the first place $[13,14]$. The TEMP-TMA/MV system achieved a capacity of $54 \mathrm{Ah} \cdot \mathrm{L}^{-1}$ at a concentration of 
$2 \mathrm{~mol} \cdot \mathrm{L}^{-1}$, displaying a total energy density of $38 \mathrm{Wh} \cdot \mathrm{L}^{-1}$ at a cell voltage of $1.4 \mathrm{~V}$ [14]. The ferrocyanide/anthraquinone system was cycled at a constant current density of $100 \mathrm{~mA} \cdot \mathrm{cm}^{-2}$ for 100 charging/discharging cycles, resulting in a coulombic efficiency of over $99 \%$ with a stable round-trip efficiency of $84 \%$ and $0.1 \%$ /cycle loss of capacity, which was expected to be negligible when the system size was scaled up [13]. Yet the most challenging issue for the development of organic redox flow batteries (ORFBs) remains relatively low energy density. Possible approaches to this challenge lie in broadening the electrochemical window (ECW), enhancing the solubility and/or redox potential of the redox-active materials [5]. Non-aqueous solvents have a rather expanded ECW varying from -4 to $2.3 \mathrm{~V}$ (vs. ferrocene/ferrocenium) [15]. In contrast, the ECW of aqueous ORFBs is greatly constrained by the water stability window $(\sim 1.23 \mathrm{~V})$. Despite the superiority of the wide ECW of non-aqueous ORFBs, they face several challenges including flammability, poor solubility of the redox pairs in organic solvents, high viscosity and low conductivity of electrolyte solutions as well as a special membrane design which is required to resist against swelling by organic solvents [16]. Comparatively, aqueous ORFBs have the merits of a low-cost solvent (water) and supporting electrolytes (basically, inorganic salts), high ion conductivity, fast kinetics and, most importantly, long-term safety for practical applications $[1,17]$. As the redox potential varies with the $\mathrm{pH}$ value of the electrolyte solution, it is possible to enlarge the ECW of water to some extent. There are also examples of applying highly concentrated electrolytes to broaden the voltage window of the aqueous ORFBs $[15,18]$. Although there have been limited improvements to enlarging the cell voltage of aqueous ORFBs, it has indeed been possible to design new redox pairs with high solubility to fit into the water stability window. Meanwhile, with the help of theoretical computing methods such as density-functional theory (DFT), researchers have been able to screen for promising candidates from numerous alternatives, which will accelerate the development of new redox pairs $[19,20]$. Another notable way of raising energy density lies in increasing the number of electrons stored per molecule, e.g., using quinones instead of TEMPO radicals.

Organic molecules are flexible regarding tailoring their properties. For instance, positively or negatively charged ions can be easily incorporated into parent molecules to be well compatible with anion or cation exchange membranes, meanwhile enhancing solubility in aqueous solutions. The redox potential of organic molecules can be shifted within a certain range by introducing electron-withdrawing groups (EWGs) or electron-donating groups (EDGs) $[21,22]$. As promising candidates, quinone/hydroquinone derivatives have advantages over other types of redox-active organic molecules. They deliver two electrons for each half-cell reaction and can serve as both catholytes and anolytes, which is an intriguing point regarding building metal-free all-quinone based ORFBs [21]. In a previous work, 28 quinone derivatives were investigated systematically in aqueous solutions using cyclic voltammetry (CV) and other techniques [4]. 2,6-anthraquinone disulfonic acid (2,6-AQDS), 2,7-anthraquinone disulfonic acid (2,7-AQDS) and their derivatives can be employed as anolytes in aqueous RFBs, whereas hydroquinones (HQs) have sufficiently positive redox potential to be used as catholytes. Although AQDS is known for its low cost, high solubility, chemical stability and rapid redox kinetics [23], it forms electrochemically inactive dimers at the concentrations employed for practical applications, which indirectly decreases the energy storage capacity [24-26]. Most known HQs with high redox potential are not sufficiently stable for flow battery applications [4]. Hence, there is an urgent need to develop stable and highly soluble HQs for the use in ORFBs, in particular for the positive electrode of the battery, i.e., catholyte solution. In hydroquinone form, all of the unsubstituted carbon atoms in the aromatic ring are prone to electrophilic substitution and nucleophile substitution for the quinone form, i.e., the Michael addition reaction $[27,28]$. Our supposition is that if these unsubstituted carbon atoms are blocked, this could lead to more stable molecules. It has further been revealed that the 1,2- and 1,4-HQs represent promising candidates as catholytes for ORFBs, wherein the fully substituted HQs could gain greatly enhanced solubility in aqueous solutions [4]. Moreover, fully substituted 
HQs are supposed to mitigate side reactions, either by blocking radical transfer via the tautomerization of the relatively acidic aromatic protons, or by the introduction of steric, kinetic hindrance using bulky functional groups such as morpholinomethylene [29]. To validate the hypothesis, a HQ fully substituted by tetramorpholinomethylene groups (TMHQ) was synthesized and tested at a concentration of $0.1 \mathrm{M}$ in $1 \mathrm{M} \mathrm{NH}_{4} \mathrm{Cl}$ in a symmetric flow cell set-up [30]. In acidic conditions, the morpholinomethylene group was protonated to obtain a quaternary ammonium group, turning the EDG into an EWG. Consequently, the redox potential was shifted to $0.89 \mathrm{~V}$. The molecule featured a high solubility (2 $\mathrm{M}$ in $37 \%$ hydrochloric acid). However, the capacity retention over 100 charging/discharging cycles was only 33\%, with a potentiostatic cycling between -0.3 and $0.3 \mathrm{~V}$, far below expectations. Hence, a deeper understanding of the stability of HQs is necessary for guiding the future design of HQ derivatives possessing both high solubility and stability.

Therefore, a series of four HQ derivatives incorporating the morpholinomethylene and/or methyl groups were designed to understand the relationship between the structure of this particular compound class and the important parameters of a redox flow battery. The influence of molecular structure on the solubility of the four molecules were thoroughly discussed in our previous report [31]. In this work, the stability of the four molecules was investigated in symmetric flow cells in different supporting electrolytes using different cycling methods. Among them, 2,5-bis(morpholinomethylene)benzene-1,4diol (O-3) was substituted with two morpholinomethylene groups in symmetric positions without protecting the other two ortho positions. As a comparison, 2,5-dimethyl-3,6bis(morpholinomethylene)benzene-1,4-diol (O-5) was fully substituted on the basis of O-3, where the unprotected ortho positions were occupied by two methyl groups. 2,6dimethyl-3,5-bis(morpholinomethylene)benzene-1,4-diol (asym-O-5) possessed the same chemical composition as $\mathbf{0 - 5}$ but with molecular central asymmetry. The fourth molecule was 2,3,5-trimethyl-6-(morpholinomethylene)benzene-1,4-diol (O-1), which was fully substituted with one morpholinomethylene group and three methyl groups. The capacity decay rate of symmetric cells revealed the stability of the given molecule. Our goal was to check the importance of protecting the ortho positions of hydroquinones and to prove our supposition that fully substituted hydroquinones are stable and exhibit high accessible capacity, beneficial for flow battery applications.

\section{Results}

\subsection{Reversibility and Redox Potential}

The electrochemical reversibility of the four molecules was investigated via cyclic voltammetry $(\mathrm{CV})$, and the redox potentials were obtained, as shown in Figure 1 . The oxidation of hydroquinones involved a two-electron transfer process coupled with proton transfer. The cathodic peak current $\left(i_{\mathrm{pc}}\right)$ and the anodic peak current $\left(i_{\mathrm{pa}}\right)$ could provide information on the reversibility of the redox-active molecules. When $i_{\mathrm{pa}} / i_{\mathrm{pc}}$ equaled or was very close to one, it indicated the reversibility of the investigated molecules such as in the cases of O-1, O-5 and asym-O-5 (Figure $1 \mathrm{a}-\mathrm{d}$ ). When $i_{\mathrm{pa}} / i_{\mathrm{pc}}$ was far from one, for example, the value for $\mathbf{O}-3$ was 1.5 (Figure 1b), and it was irreversible. In a two-electron transfer half-cell reaction, the ideal peak separation $\Delta \mathrm{E}_{\mathrm{p}}$ was $29.5 \mathrm{mV}$ for an electrochemically reversible process. The peak separation for the four molecules ranged from 380 to $608 \mathrm{mV}$, way beyond the theoretical expectation. This phenomenon was assigned to the low kinetics on the glassy carbon electrode [32]. 

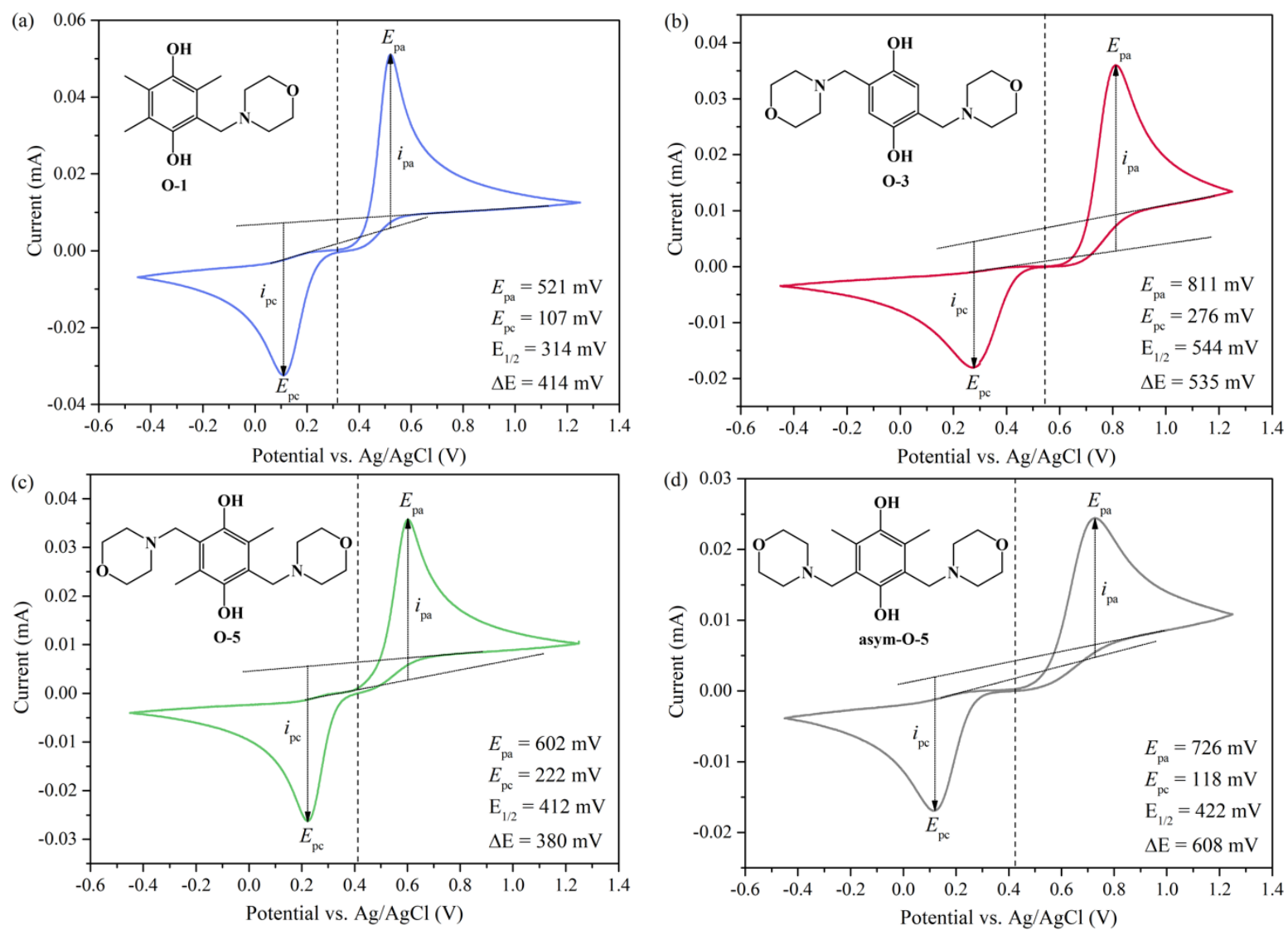

Figure 1. Cyclic voltammographs of hydroquinones (a) O-1, (b) O-3, (c) O-5 and (d) asym-O-5 measured at a scan rate of $100 \mathrm{mV} \cdot \mathrm{s}^{-1}$ in $1 \mathrm{M} \mathrm{H}_{2} \mathrm{SO}_{4}$. The chemical structures of the four molecules are presented in the top-left corner of the corresponding subfigures. The dashed line indicates the half-wave potential $\mathrm{E}_{1 / 2} \mathrm{vs}$. Ag/ $\mathrm{AgCl}$.

Upon being dissolved in $\mathrm{H}_{2} \mathrm{SO}_{4}$, the morpholinomethylene group changed from an EDG to an EWG, as it was protonated to a quaternary ammonium cation, enhancing the solubility as well as leading to redox potential shift toward positive values. As an EDG, the methyl group decreased the redox potential. Consequently, the lowest redox potential of $0.54 \mathrm{~V}$ was assigned to $\mathbf{O}-1$, which bore three electron-donating methyl groups and one electron-withdrawing morpholinomethylene group. In contrast, the redox potential of O-5 was more positive $(0.64 \mathrm{~V})$ because it had one less methyl group and one more morpholinomethylene group than O-1. Asym-O-5 had the same substituent groups but in different positions on the benzene ring, resulting in a redox potential $(0.65 \mathrm{~V})$ close to that of $\mathrm{O}-5$. With no methyl group present, $\mathrm{O}-3$ revealed the highest redox potential of $0.77 \mathrm{~V}$.

\subsection{Symmetric Cell Cycling Tests}

In symmetric cell cycling tests, identical solutions of the substance to be analyzed were employed for anolytes and catholytes (Scheme 1). Starting from a state of charge (SOCs) of $50 \%$, the battery was charged and discharged repeatedly, and the capacity was monitored.

Generally, in a full cell setup, the capacity fade involves several mechanisms, mainly stemming from electrolyte degradation, membrane crossover and side reactions. In a symmetric cell, however, as exactly the same electrolyte composition is applied on both sides of the cell, capacity fade due to cross-contamination of the redox-active species can be excluded. Therefore, the capacity decay of the cell over time indicates the chemical stability of the investigated molecules, i.e., the stability of redox-active molecules can be quantified as the capacity decay per unit time $[33,34]$. 
<smiles>[R]C1=C([R])C(=O)C([R])=C([R])C1=O</smiles>
discharging of the battery.

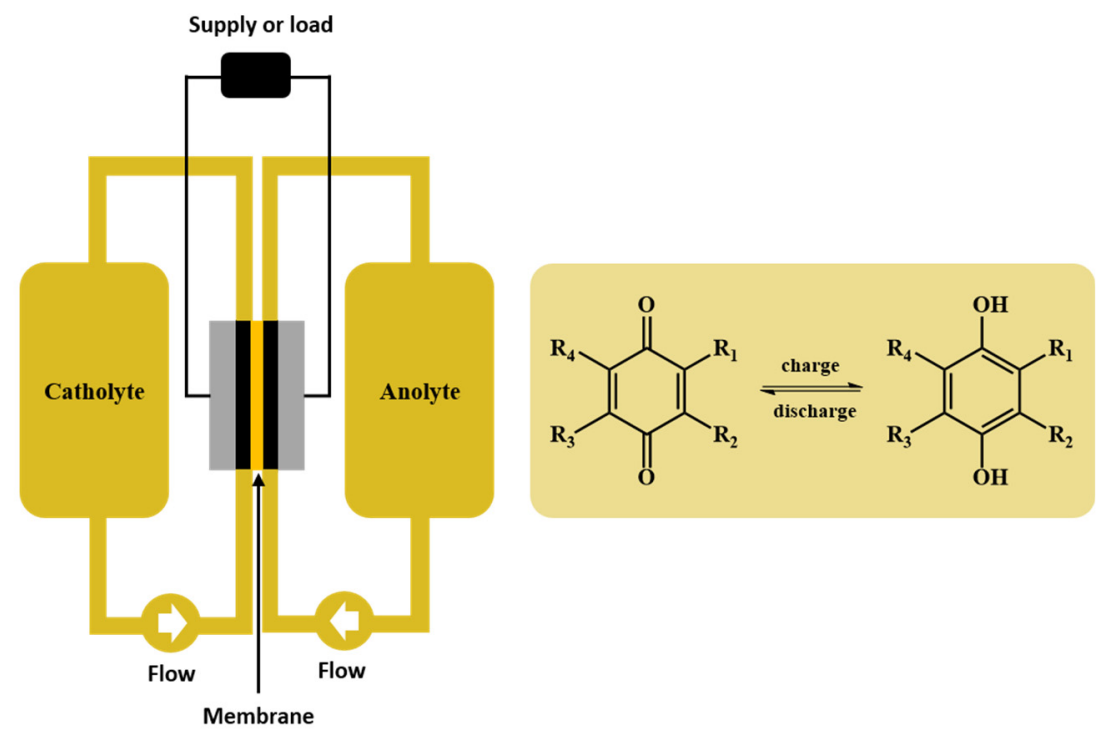

Scheme 1. Schematic representation of the redox flow battery setup and the redox reactions occurring upon charging and

\subsubsection{Stability}

The stability of the four hydroquinone derivatives was primarily investigated in a symmetric cell setup at a concentration of $0.1 \mathrm{M}$ in $1 \mathrm{M} \mathrm{H}_{3} \mathrm{PO}_{4}$, a solvent in which all four molecules were well soluble (0.48 M for O-1, 0.53 M for O-3, 0.40 M for O-5 and 0.55 M for asym-0-5) [31]. An anion-exchange membrane was employed to retain the protonated, cationic hydroquinones and conduct the counter ions at the same time.

In this kind of test, two cycling methods are commonly employed, the potentiostatic (PS) and the galvanostatic (GS) cycling method. PS cycling is more encouraged than GS cycling, in particular for molecules with low decomposition rates [34]. It is less vulnerable to changes in cell resistance and can access higher shares of the theoretical capacity than the GS cycling method [33]. As $\mathrm{H}_{3} \mathrm{PO}_{4}$ is a weak electrolyte, its solution conductivity is lower than $\mathrm{H}_{2} \mathrm{SO}_{4}$ at the same concentration. Therefore, the PS cycling method was employed as the standard method in this work.

The capacity fade of the four hydroquinones over time after being charged/discharged at a constant potential of $0.3 /-0.3 \mathrm{~V}$ for over 300 cycles is shown in Figure 2 . They displayed distinctly different capacity decay rates in $1 \mathrm{M} \mathrm{H}_{3} \mathrm{PO}_{4}$. O-3, bearing only two substituents on the hydroquinone core and two unprotected ortho positions, showed the lowest stability with a capacity drop of $71 \%$ in less than two days. The cell of $\mathbf{0}-\mathbf{1}$ exhibited a moderately fast decay at $7.3 \%$ per day and $0.190 \%$ per cycle for 263 cycles. O-5 displayed a decay of $0.87 \%$ /day and $0.099 \%$ /cycle calculated from its peak capacity (day 10). After four weeks of cycling, the final capacity of the cell with 0-5 remained at $70 \%$ of its theoretical value. As a comparison, the capacity decay of asym-O-5 was $0.45 \%$ / day and $0.058 \%$ / cycle over four-week cycling for 223 cycles. Even though the capacity decay curves of 0-1 and 0-5 were not smooth at the beginning, one could easily identify asym-O-5 as the most stable among the four molecules, whereas $\mathbf{O}-3$ was the least stable. This observation provides evidence for the claim that the ortho positions of hydroquinones need to be occupied to ensure their chemical stability in aqueous solutions [4]. 


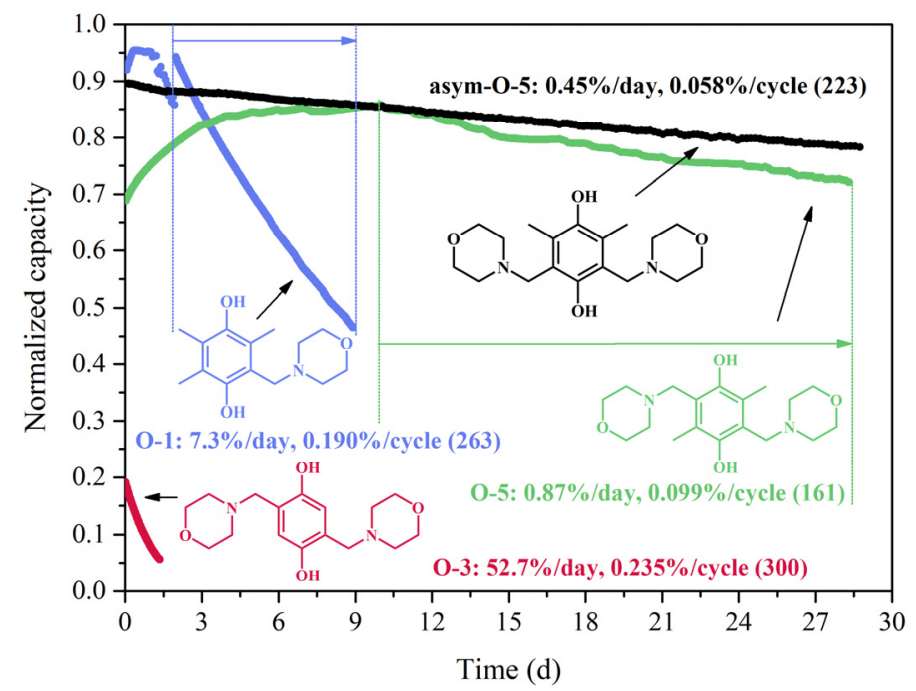

Figure 2. Discharge capacity of the symmetric cells of $0.1 \mathrm{M} \mathrm{O-1,0-3,} \mathrm{O-5}$ and asym-O-5 in $1 \mathrm{M}$ $\mathrm{H}_{3} \mathrm{PO}_{4}$ using the PS cycling method. The $y$-axis is normalized by dividing the discharge capacity value by its theoretical capacity. The potential is set at $0.3 /-0.3 \mathrm{~V}$ for charge/discharge cycles with cut-off current at $3 /-3 \mathrm{~mA}$.

After cycling, the electrolyte solution of $\mathbf{O}-\mathbf{3}$ was investigated by liquid chromatographymass spectroscopy (LC-MS), and 2,5-dioxoterephthalic acid was identified as the decomposition product. The derived decomposition pathway of O-3 (Figure 3a) was found to be similar to that of TMHQ as reported in a previous work [30]. As both the 2,5-dihydroxyterephthalic acid and its quinonic analogue were poorly soluble in water, a white precipitate was found on the surface of the carbon-felt electrode after the flow cell was dismantled. The chemical identity of the by-product was further confirmed by comparing the chromatographic and spectroscopic (UV and MS) properties of the electrochemically oxidized, commercially available dihydroxy terephthalic acid, which were found to be identic.

In summary, the high instability of O-3 necessitated the protection of all four ortho positions of 1,4-HQ. Among the three fully substituted hydroquinones, the substitution of two morpholinomethylene and two methyl groups (O-5 and asym-O-5) was more stable than that of one morpholinomethylene and three methyl groups (O-1). It is noteworthy that O-3 had a rather low initial normalized capacity $(\sim 20 \%)$ compared to the other three molecules (above $70 \%$ ). This difference was assigned to the rapid capacity decay rate of O-3 (rf. Section 2.2.3 for details).

\subsubsection{PS vs. GS Cycling Method}

As mentioned previously, the preferred method to determine the stability of investigated molecules through a symmetric cell cycling test is the PS method, as it eliminates the influence of the changing cell resistance amid the cycling process [33]. In practical applications, the charge/discharge process may include both PS and GS steps. Therefore, the GS cycling method was studied as an additional way to look at the stability of O-1, O-3, O-5 and asym-O-5, thereby comparing it with the PS cycling method (Table 1). As $\mathrm{H}_{3} \mathrm{PO}_{4}$ was less conductive, and the GS cycling method was vulnerable to changing cell resistance, $\mathrm{H}_{2} \mathrm{SO}_{4}$ was chosen as the supporting electrolyte except in $\mathbf{O}-\mathbf{3}$, which was poorly soluble in $\mathrm{H}_{2} \mathrm{SO}_{4}$. 
(a)<smiles>CC(C)CC1COCC[N+]1(C)CC1=CC(=O)C(C[NH+]2CCOCC2)=CC1=O</smiles><smiles>Oc1cc(C[N+]2(C=c3cc(O)c(=CN4CCOCC4)cc3O)CCOCC2)c(O)cc1C[NH+]1CCOCC1</smiles>

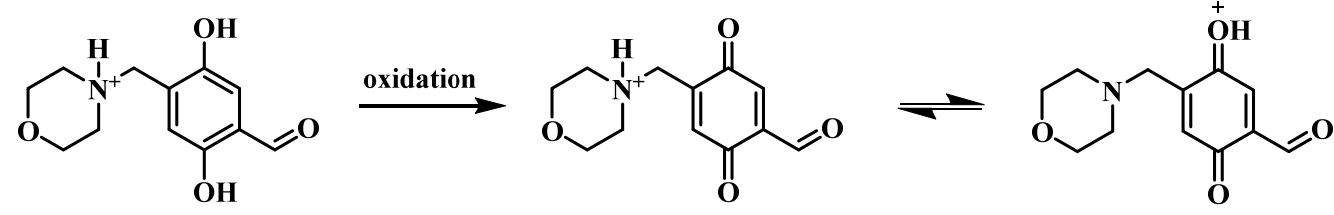

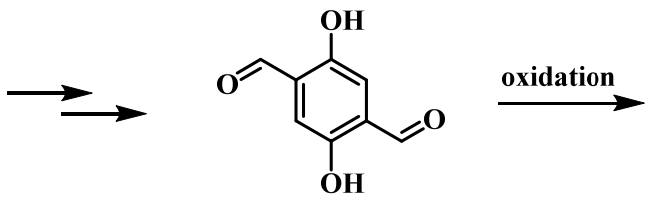<smiles>O=C(O)C1=CC(=O)C(C(=O)O)=CC1=O</smiles>

(b)<smiles>Oc1c(CN2CCOCC2)c(CN2CCOCC2)c(O)c(CN2CCOCC2)c1CN1CCOCC1</smiles>

isolated byproduct

\section{TMHQ}

Figure 3. (a) Schematic representation of the proposed decomposition pathway of $\mathbf{O}-\mathbf{3}$; (b) schematic representation of the chemical structure of TMHQ.

Table 1. Symmetric cell cycling tests of O-1, O-3, O-5 and asym-O-5, using the PS and GS cycling methods.

\begin{tabular}{cccc}
\hline Condition & Method & Cell Resistance/ $\Omega$ & Capacity Decay Rate (Cycle) \\
\hline O-1: $0.05 \mathrm{M}, 1 \mathrm{M} \mathrm{H}_{2} \mathrm{SO}_{4}$ & $\mathrm{GS}$ & $0.135 / 0.120$ & $2.9 \% /$ day, $0.072 \% /$ cycle $(378)$ \\
O-1: $0.1 \mathrm{M}, 1 \mathrm{M} \mathrm{H}_{2} \mathrm{SO}_{4}$ & $\mathrm{PS}$ & $0.175 / 0.116$ & $5.7 \% /$ day, $0.117 \% /$ cycle $(276)$ \\
\hline O-3: $0.1 \mathrm{M}, 1 \mathrm{M} \mathrm{H}_{3} \mathrm{PO}_{4}$ & $\mathrm{GS}$ & $0.456 / 0.357$ & $48.5 \% /$ day, $0.43 \% / \mathrm{cycle}(221)$ \\
O-3: $0.1 \mathrm{M}, 1 \mathrm{M} \mathrm{H}_{3} \mathrm{PO}_{4}$ & $\mathrm{PS}$ & $0.380 / 0.346$ & $52.7 \% /$ day, $0.235 \% /$ cycle $(300)$ \\
\hline O-5: $0.075 \mathrm{M}, 1 \mathrm{M} \mathrm{H}_{2} \mathrm{SO}_{4}$ & $\mathrm{GS}$ & $0.169 / 0.160$ & $1.1 \% /$ day, $0.069 \% / \mathrm{cycle}(179)$ \\
O-5: $0.05 \mathrm{M}, 1 \mathrm{M} \mathrm{H}_{2} \mathrm{SO}_{4}$ & $\mathrm{PS}$ & $0.155 / 0.125$ & $0.78 \% /$ day, $0.056 \% /$ cycle $(253)$ \\
\hline Asym-O-5: $0.1 \mathrm{M}, 1 \mathrm{M} \mathrm{H}_{2} \mathrm{SO}_{4}$ & $\mathrm{GS}$ & $0.134 / 0.122$ & $1.8 \% /$ day, $0.204 \% / \mathrm{cycle}(179)$ \\
Asym-O-5: $0.1 \mathrm{M}, 1 \mathrm{M} \mathrm{H}_{2} \mathrm{SO}_{4}$ & $\mathrm{PS}$ & $0.144 / 0.128$ & $0.46 \% /$ day, $0.042 \% /$ cycle $(309)$ \\
\hline
\end{tabular}

Obviously, for all four molecules, a significant difference in capacity decay rate was found when using different cycling methods. When the PS cycling method was applied, the overall stability trend stayed the same in $\mathrm{H}_{2} \mathrm{SO}_{4}$ as in $\mathrm{H}_{3} \mathrm{PO}_{4}$, i.e., asym-O-5 > O$5>$ O-1 > O-3 (Figure 4). However, when the molecules were charged/discharged at a constant current, the capacity decay of the four molecules displayed non-ignorable difference from the PS cycling method. In particular, O-5 exhibited the lowest capacity 
decay rate, presenting higher stability than asym-O-5. It should be noted that several parameters could influence the observed capacity decay rate, e.g., reactant concentration and state of charge (SOC). On the one hand, higher reactant concentration (starting from $0.1 \mathrm{M}$ ) has been observed in the literature to result in lower capacity retention, which relates mainly to the reactant's stability [35]. On the other hand, it was reported that $0.1 \mathrm{M}$ 2,6-DHAQ in $1 \mathrm{M} \mathrm{KOH}$ experienced much faster capacity decay (around 10\%/day) at $100 \%$ SOC than at 50\% SOC (around 1\%/day) [33]. For 0.1 M 2,7-AQDS in $1 \mathrm{M} \mathrm{H}_{2} \mathrm{SO}_{4}$, the average capacity decay was found to be $0.08 \pm 0.02 \% /$ day. The highest capacity observed was $0.2 \%$ /day at $100 \%$ SOC [33]. To confirm whether this observation was applicable to hydroquinones, the SOC of $\mathbf{O - 1}$ was changed by altering the cut-off voltage and charging current. When the charge/discharge current of O-1 was $50 \mathrm{~mA}, 62.5 \%$ of the theoretical capacity was achieved before it reached the cut-off voltage. When the charge-discharge current decreased to $30 \mathrm{~mA}$ and the cut-off voltage to $0.2 /-0.2 \mathrm{~V}$, the accessible capacity decreased, and the capacity decay dropped accordingly. Therefore, the lower initial concentration and SOC collectively led to the lower capacity decay rate of O-1 when using the GS cycling method (Figure 4a). Similarly, the SOC of O-5 was reduced by lowering the applied potential, and the corresponding rate of capacity decay decreased (Figure 4c). It is interesting that $\mathbf{O}-\mathbf{5}$ and asym-O-5 stood at similar starting points upon charging and discharging, but the capacity of the cell with asym-O-5 decayed faster compared to $\mathbf{O}-\mathbf{5}$ at a constant discharging potential. This might be assigned to the influence of reactant concentration (Table 1). Similar to using the PS cycling method, due to its fast decomposition, $\mathbf{O}-3$ revealed a high-capacity decay rate when using the GS cycling method at $0.1 \mathrm{M}$ concentration in $1 \mathrm{M} \mathrm{H}_{3} \mathrm{PO}_{4}$ (Figure 3). The capacity was almost used up within two days. Nevertheless, it is worth noting that the GS cell could access a higher share of the theoretical capacity in its initial cycles at a charge/discharge current of $30 /-30 \mathrm{~mA}$ (Figure $4 \mathrm{~b}$ ).

Furthermore, apparent capacity fluctuations were observed for both $0-5$ and asymO-5, using the GS cycling method, but not for $\mathbf{O}-\mathbf{1}$ and $\mathbf{O}-\mathbf{3}$. That was because the cell of $\mathbf{O - 1}$ was placed in a temperature-controlled chamber, while the cells of $\mathbf{O}-\mathbf{5}$ and asymO-5 were operated at room temperature (Figure A1 in Appendix A). In the case of O-3, the decomposition happened too fast to reflect upon the curve. Although temperature variation did not lead to direct capacity fade, it provided evidence for the need to use the PS cycling method to obtain a smooth trend for unfolding the actual stability of the investigated molecules.

\subsubsection{Accessible Capacity}

Redox-active molecules with good solubility and stability represent promising materials for practical flow battery application. Their electrolyte utilization is also an important factor in order to achieve high accessible capacity, meaning the ratio of practically observed discharge capacity over its theoretical value as given by the concentration of the redoxactive molecule and the solution volume. Table 2 summarizes the accessible capacity of the four molecules in $1 \mathrm{M} \mathrm{H}_{3} \mathrm{PO}_{4}$ and $\mathrm{H}_{2} \mathrm{SO}_{4}$, acquired using the PS cycling method. O-3 showed the least accessible capacity (20\%), O-5 and asym-O-5 ranked in the middle and the cell of O-1 utilized almost its full capacity $\left(96 \%\right.$ in $\mathrm{H}_{3} \mathrm{PO}_{4}$ and $97 \%$ in $\left.\mathrm{H}_{2} \mathrm{SO}_{4}\right)$. 

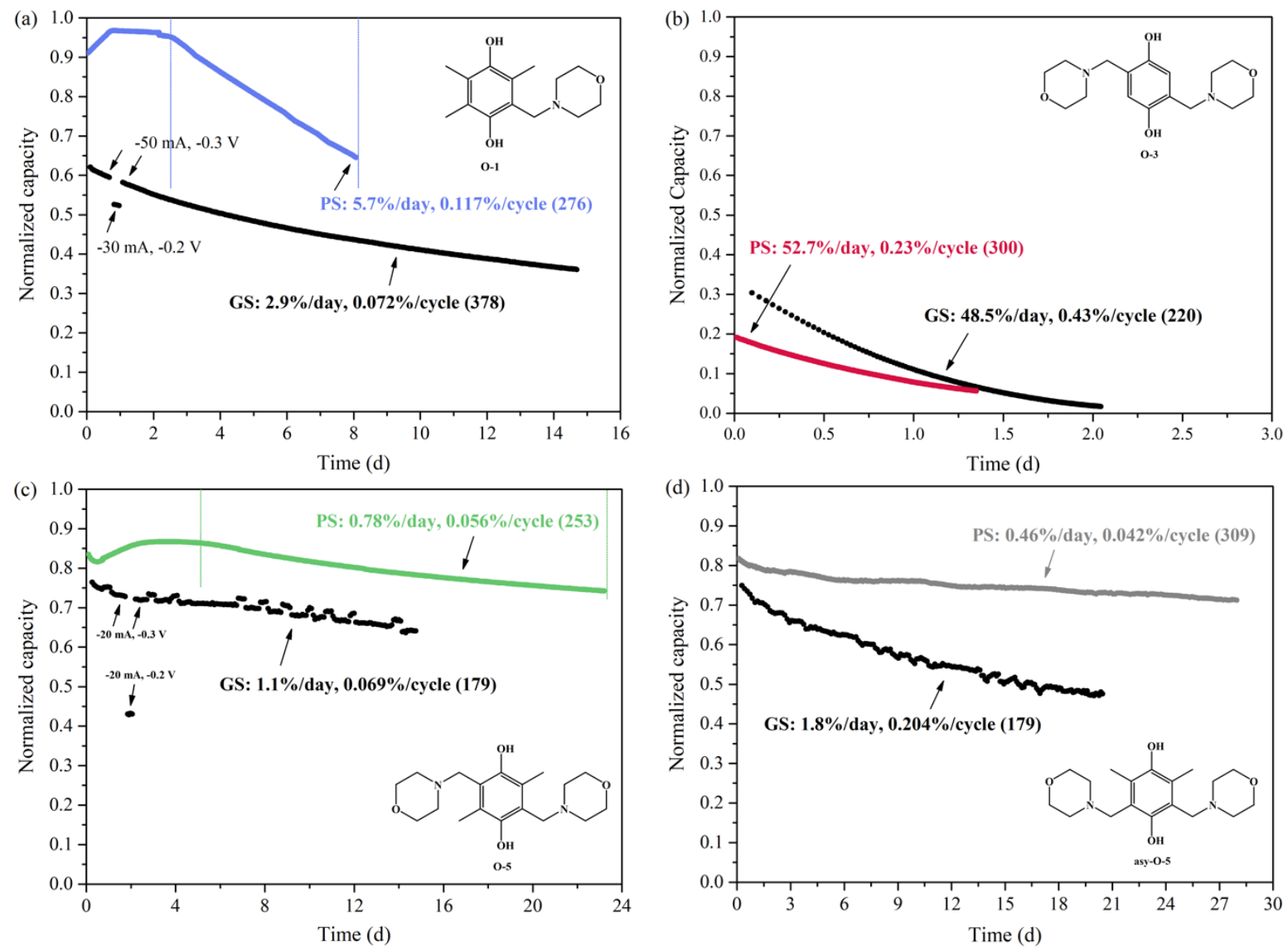

Figure 4. Discharge capacity of the symmetric cell tests of (a) $\mathbf{O}-\mathbf{1},(\mathbf{b}) \mathbf{O}-\mathbf{3}$, (c) $\mathbf{0}-\mathbf{5}$ and (d) asym-O-5 using the PS and GS cycling methods. The $y$-axis is normalized by dividing the discharge capacity value by its theoretical capacity. The potential was set at $0.3 /-0.3 \mathrm{~V}$ with cut-off current at $3 /-3 \mathrm{~mA}$ for the PS cycling method. The charge/discharge current applied in the GS cycling method was 50/-50 mA for O-1, 30/-30 mA for O-3 and 20/-20 mA for O-5 and asym-O-5 with a cut-off voltage of $0.3 /-0.3 \mathrm{~V}$.

Table 2. Accessible capacity of the four hydroquinones.

\begin{tabular}{ccc}
\hline Catholyte & Anolyte & Accessible Capacity \\
\hline $0.1 \mathrm{M} \mathrm{O}-1$ in $1 \mathrm{M} \mathrm{H}_{3} \mathrm{PO}_{4}$ & $0.1 \mathrm{M} \mathrm{O}-1$ in $1 \mathrm{M} \mathrm{H}_{3} \mathrm{PO}_{4}$ & $96 \%$ \\
$0.1 \mathrm{M} \mathrm{O}-3$ in $1 \mathrm{M} \mathrm{H}_{3} \mathrm{PO}_{4}$ & $0.1 \mathrm{M} \mathrm{O}-3$ in $1 \mathrm{M} \mathrm{H}_{3} \mathrm{PO}_{4}$ & $20 \%$ \\
$0.1 \mathrm{M} \mathrm{O}-5$ in $1 \mathrm{M} \mathrm{H}_{3} \mathrm{PO}_{4}$ & $0.1 \mathrm{M} \mathrm{O}-5$ in $1 \mathrm{M} \mathrm{H}_{3} \mathrm{PO}_{4}$ & $85 \%$ \\
$0.1 \mathrm{M}$ asym-O-5 in $1 \mathrm{M} \mathrm{H}_{3} \mathrm{PO}_{4}$ & $0.1 \mathrm{M}$ asym-O-5 in $1 \mathrm{M} \mathrm{H}_{3} \mathrm{PO}_{4}$ & $90 \%$ \\
\hline $0.1 \mathrm{M} \mathrm{O}-1$ in $1 \mathrm{M} \mathrm{H}_{2} \mathrm{SO}_{4}$ & $0.1 \mathrm{M} \mathrm{O-1}$ in $1 \mathrm{M} \mathrm{H}_{2} \mathrm{SO}_{4}$ & $97 \%$ \\
$0.05 \mathrm{M}$ O-5 in $1 \mathrm{M} \mathrm{H}_{2} \mathrm{SO}_{4}$ & $0.05 \mathrm{M}$ O-5 in $1 \mathrm{M} \mathrm{H}_{2} \mathrm{SO}_{4}$ & $88 \%$ \\
$0.1 \mathrm{M}$ asym-O-5 in $1 \mathrm{M} \mathrm{H}_{2} \mathrm{SO}_{4}$ & $0.1 \mathrm{M}$ asym-O-5 in $1 \mathrm{M} \mathrm{H}_{2} \mathrm{SO}_{4}$ & $82 \%$ \\
\hline
\end{tabular}

Apparently, all four hydroquinones derivatives were unable to use the full theoretical capacity right from the beginning. This effect is known from the literature, as many quinonebased systems suffer from poor accessible charge capacity due to the dimerization of the redox-active species [25]. There are two kinds of dimerization. One is the formation of dimers upon dissolving the substance in a solvent. The other one arises from the association of the hydroquinone with its oxidized quinone form, i.e., quinhydrone formation [24]. As a result, the two-electron transfer in one half-reaction is usually hindered at concentrations commonly employed in practical flow batteries.

One way to recognize the formation of quinhydrone is the apparent color change of the solution once charged in the flow cell. For instance, electrochemical studies on anthraquinone derivatives have shown that the formation of a hydroxyanthraquinone- 
anthraquinone dimer leads to an apparent solution color change from yellow/colorless to green $[24,36]$. The color change of $\mathbf{O}-\mathbf{1}, \mathbf{O}-\mathbf{3}, \mathbf{O}-\mathbf{5}$ and asym-O-5 solutions over different SOCs suggested that the investigated hydroquinones formed quinhydrones (Figure 5).
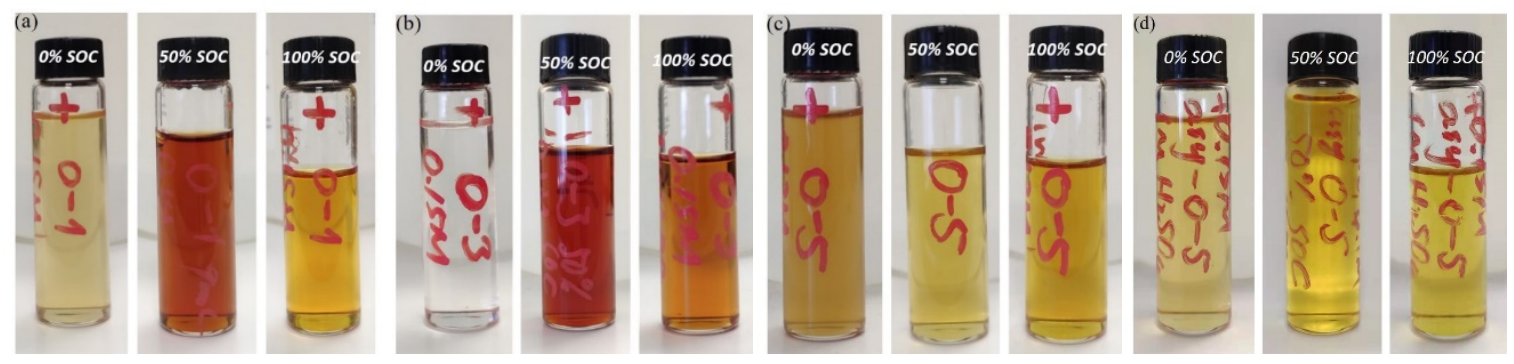

Figure 5. Colors of hydroquinone solutions at different SOCs, indicating the charge/discharge status of the flow cell. (a) $0.15 \mathrm{M}$ O-1 in $1 \mathrm{M} \mathrm{H}_{2} \mathrm{SO}_{4}$ at $\%$ (light yellow), $50 \%$ (red) and 100\% (orange) SOC; (b) $0.15 \mathrm{M} \mathrm{O-3}$ in $1 \mathrm{M} \mathrm{H}_{3} \mathrm{PO}_{4}$ at $0 \%$ (colorless), $50 \%$ (red) and $100 \%$ (orange red) SOC; (c) $0.1 \mathrm{M} \mathrm{O}-5$ in $1 \mathrm{M} \mathrm{H}_{2} \mathrm{SO}_{4}$ at $\%$ (orange red), $50 \%$ (light yellow) and $100 \%$ (bright yellow) SOC; (d) $0.15 \mathrm{M}$ asym-O-5 in $1 \mathrm{M} \mathrm{H}_{2} \mathrm{SO}_{4}$ at $0 \%$ (light yellow), $50 \%$ (yellow) and $100 \%$ (bright yellow) SOC.

Looking at the data of Figure 2 in detail, O-1 accessed $92 \%$ of its theoretical capacity in the first charge/discharge cycle. It then directly climbed up to $96 \%$ in a half-day period and held for two days before it started to decline. For comparison, in the symmetric cell cycling test of TMHQ using the PS cycling method, a similar plateau at the starting point of the capacity decay curve was found in a literature example, where it held at $92 \%$ of its theoretical capacity for five cycles before its fast decay [30]. In another work, Hagemann investigated the cycling stability of a new, polymer-based catholyte using the GS cycling method, and no plateau was observed [8]. Hence, the existence of this plateau may be related to the cycling method. This observation was supported by studies of $\mathbf{0 - 1}, \mathbf{O}-\mathbf{3}$, O-5 and asym-O-5 where no capacity-holding period was observed when applying the GS cycling method (Figure 4). In addition, symmetric cell cycling tests of $0.1 \mathrm{M} \mathrm{O-1}$ in different supporting electrolytes, applying different cycling methods were performed as further evidence to explain this plateau phenomenon (Figure A2 in Appendix A).

The charge/discharge capacity of $\mathbf{O}-5$ experienced a slow increase in the first ten days and then underwent a constant decay. Likewise, this phenomenon was related to the cycling method applied. In an independent experiment, the symmetric cell cycling tests of O-5 were performed in different supporting electrolytes at a concentration of $0.1 \mathrm{M}$ while using the same PS cycling method. The period of capacity increase from the beginning was apparent in both $1 \mathrm{M} \mathrm{H}_{2} \mathrm{SO}_{4}$ and $\mathrm{H}_{3} \mathrm{PO}_{4}$ (Figures 2 and $4 \mathrm{c}$, green curves). Peak values were at about $85 \%$ and $88 \%$ of theoretical capacity. In contrast, the cell for preparation of the $100 \%$ SOC solution of O-5 against vanadium(III) successfully achieved $99.8 \%$ of the theoretical capacity, indicating the material's capability to access full capacity at a concentration of $0.1 \mathrm{M}$ and suggesting that the formation of dimers from two single molecules of $\mathbf{O}-\mathbf{5}$ was reversible. Surprisingly, the cell of asym-O-5, for which the electrolyte reservoirs were cooled by water bath, did not undergo a long period of pre-conditioning before the capacity started to decay. This suggests that the underlying reason for the capacity increase in the cases of O-1 and O-5 might be temperature changes when applying the PS cycling method, which is supposed to affect the complicated dimerization process.

The first cycle of O-3 utilized only $20 \%$ of the theoretical capacity. In contrast, during the preparation of the $100 \%$ SOC solution, the cell reached $99.4 \%$ of the theoretical capacity, which meant that if dimers were formed in the solution, the reaction should have been highly reversible. It was possible that the dimerization constant for quinhydrone formation was large enough to hinder the reverse reaction, as $100 \%$ SOC solution of $\mathbf{O}-3$ was prepared successfully against $\mathrm{V}(\mathrm{III})$. Under the same conditions, $\mathbf{0 - 1}$ and $\mathbf{0 - 5}$ both displayed a period of capacity increase before the capacity started to drop. As this was not observed in the case of $\mathbf{O}-3$, it was safe to assume the decomposition of $\mathbf{O}-\mathbf{3}$ started to occur as 
soon as the hydroquinone was fully oxidized during the preparation of the symmetric cell test setup.

\section{Discussion}

The symmetric cell cycling tests of the four hydroquinones unfold their stability in a good way and provide solid evidence for the importance of fully protecting the ortho positions of HQs. In 2018, Goulet et al. published a systematic study determining the stability of 2,7-AQDS, 2,6-DHAQ, MV and bis(trimethylammoniopropyl)viologen (BTMAPV) at a concentration of $0.1 \mathrm{M}$ [33]. The two quinone derivatives, 2,7-AQDS and DHAQ, exhibited a capacity decay rate of $0.08 \sim 0.2 \%$ /day and $1 \sim 10 \%$ /day, respectively, depending on the SOC. The viologen derivative MV showed a capacity decay rate of $1.5 \%$ / day, whereas cycling of BTMAPV (bis(trimethylammoniopropyl)viologen) displayed negligible capacity loss (within measuring error) over a two-week operation. Referring to the classification by Aziz et al. the capacity decay rate of $>1 \%$ /day is categorized to be 'high', $0.1 \sim 1 \%$ /day is regarded as 'moderate' and $<0.02 \% /$ day is 'low' [34]. In this work, the most stable asym-O-5 had a capacity decay rate of $0.45 \%$ /day (Table 3 ) at $0.1 \mathrm{M}$ in $1 \mathrm{M} \mathrm{H}_{3} \mathrm{PO}_{4}$, even upon cycling to a high SOC value (90\%). The moderately low capacity decay rate of asym-O-5 demonstrated that it was a reliable, redox-active hydroquinone alternative that could be used as a catholyte and suggested the benefit of substituting all benzylic protons. As an alternative candidate for flow battery application, $\mathbf{0}-5$ had a capacity decay rate of 0.78 to $1.1 \%$ /day depending on the supporting electrolytes, cycling method and concentration. However, it should be noted that solubility of $\mathrm{O}-5$ in $\mathrm{H}_{2} \mathrm{SO}_{4}$ changed from $0.24 \mathrm{M}$ to $0.06 \mathrm{M}$ during storage over time. This effect stemmed from the formation of a less-soluble polymorph induced by molecular central symmetry [31]. In comparison, asym-O-5, bearing identical substituents as $\mathbf{O}-\mathbf{5}$ but a central asymmetry, maintained its solubility of $0.44 \mathrm{M}$ in $\mathrm{pH} 1 \mathrm{H}_{2} \mathrm{SO}_{4}$ and $0.55 \mathrm{M}$ in $\mathrm{pH} 1 \mathrm{H}_{3} \mathrm{PO}_{4}$.

Table 3. Summary of the stability of studied hydroquinones.

\begin{tabular}{cc}
\hline Molecule & Capacity Decay Rate \\
\hline O-1 & 2.9 to $7.3 \% /$ day \\
O-3 & 48.5 to $52.7 \% /$ day \\
O-5 & 0.78 to $1.1 \% /$ day \\
asym-O-5 & 0.45 to $1.8 \% /$ day \\
\hline
\end{tabular}

As a popular selection for the anolyte, AQDS suffers from poor accessible capacity due to dimerization in non-dilute solutions [25]. As shown in Table 4, the combination of $0.1 \mathrm{M}$ BQDS and $0.1 \mathrm{M}$ 2,7-AQDS in $1 \mathrm{M} \mathrm{H}_{2} \mathrm{SO}_{4}$ made $65 \%$ of theoretical capacity practically available in a flow cell. When the concentration was increased to $1 \mathrm{M}$, the accessible capacity decreased to $26 \%$, as the equilibrium shifted towards dimer formation. At the same concentration, a cell employing BQDS and 2,6-AQDS ( $1 \mathrm{M}$ in $1 \mathrm{M} \mathrm{H}_{2} \mathrm{SO}_{4}$ ) revealed an accessible capacity of $35 \%$. A third example illustrating the problem at the low concentration of $0.05 \mathrm{M}$ in $1 \mathrm{M} \mathrm{H}_{2} \mathrm{SO}_{4}$ was a flow cell using BQDS and ARS. It reached less than half of the theoretical capacity despite the low concentration. 
Table 4. Accessible capacity of quinone-based flow batteries in the literature.

\begin{tabular}{|c|c|c|}
\hline Reference & Electrolytes & Accessible Capacity \\
\hline Li et al. [37] & $0.1 \mathrm{M} \mathrm{BQDS}^{\mathrm{a}} / 0.1 \mathrm{M}$ 2,7-AQDS in $1 \mathrm{M} \mathrm{H}_{2} \mathrm{SO}_{4}$ & $65 \% \mathrm{~b}$ \\
\hline Zhang, Li and Chu [38] & $0.05 \mathrm{M} \mathrm{BQDS} / 0.05 \mathrm{M} \mathrm{ARS}^{\mathrm{c}}$ in $1 \mathrm{M} \mathrm{H}_{2} \mathrm{SO}_{4}$ & $42 \%$ \\
\hline Cao et al. [39] & $1 \mathrm{M}$ BQDS/1 M 2,7-AQDS in $1 \mathrm{M} \mathrm{H}_{2} \mathrm{SO}_{4}$ & $26 \% \mathrm{~b}$ \\
\hline Yang et al. [40] & $1 \mathrm{M}$ BQDS/1 M 2,6-AQDS in $1 \mathrm{M} \mathrm{H}_{2} \mathrm{SO}_{4}$ & $35 \%$ \\
\hline
\end{tabular}

a: BQDS: 1,2-dihydrobenzoquinone-3,5-disulfonic acid; ${ }^{b}$ : adapted from Table 1 presented by C. Wiberg et al. [25]; ${ }^{c}$ : ARS: 3,4-dihydroxy-

9,10-anthraquinone-2-sulfonic acid.

In this work, except for $\mathbf{O}-3$, which was highly unstable, three molecules exhibited high accessible capacity (Table 2, 82 97\%) in the symmetric cell test, an advantage for redox flow battery applications. In particular, O-1 could achieve $96 \%$ of its theoretical capacity in $\mathrm{H}_{3} \mathrm{PO}_{4}$ and $97 \%$ in $\mathrm{H}_{2} \mathrm{SO}_{4}$ at $0.1 \mathrm{M}$, which was maintained even when the concentration increased to $0.5 \mathrm{M}$ in a full cell test with $\mathrm{V}(\mathrm{III})$ as the anolyte (Figure A3 in Appendix A).

\section{Materials and Methods}

\subsection{Synthesis, Analytical Description and Solubility Measurements}

The synthetic methods of the compounds ${ }^{1} \mathrm{H}$ NMR, LC-MS as well as solubility data can be found in our previous report [31].

\subsection{Cyclic Voltammetry}

Cyclic voltammetry was employed to determine the redox potential of the four hydroquinones. All cyclic voltammograms were recorded using a VMP3 potentiostat (BioLogic, France) via a three-electrode cell, where a glassy carbon served as the working electrode, platinum wire as the counter electrode and silver/silver chloride as the reference electrode. A representative measurement can be described as follows:

The cell was first filled with $5 \mathrm{~mL} 1 \mathrm{M} \mathrm{H}_{2} \mathrm{SO}_{4}$ aqueous solution and then de-aerated with argon for $30 \mathrm{~s}$. The cyclic voltammograms were recorded within the water stability window from -0.45 to $1.25 \mathrm{~V}$ at a scan rate of $100 \mathrm{mV} \cdot \mathrm{s}^{-1}$. Six consecutive scans were applied to acquire credible results. Subsequently, $10 \mathrm{mg}$ sample was added to the reservoir, which was then de-aerated again and measured following the aforementioned protocol. After subtracting the background, the fourth scan was taken as the reference for calculating the redox potentials of the investigated molecules.

\subsection{Preparation of Electrolyte Solutions}

All cells mentioned in this work were based on a lab-scale single cell with an active area of $5 \mathrm{~cm}^{2}$ (JenaBatteries GmbH, Jena, Germany). The cell setup used was adapted from what was described previously [9].

Vanadium (III) preparation: The V(III) electrolyte was prepared from the $1.6 \mathrm{M}$ commercial V(IV)/V(III) mixed solution (GfE Metalle und Materialien GmbH) with N117 (Ion Power $\mathrm{GmbH}$ ) as the separator. It was charged at $20 \mathrm{~mA}$ until it reached the cut-off voltage of $1.25 \mathrm{~V}$ or its theoretical capacity. The solution obtained on the anode side (V(III)) was then used to prepare the $100 \%$ state of charge (SOC) solutions of $\mathbf{O}-\mathbf{1}, \mathbf{O}-\mathbf{3}$ and $\mathbf{O}-\mathbf{5}$.

Preparation of 50\% SOC solutions: The 50\% SOC solutions of $\mathbf{O}-\mathbf{1}, \mathbf{O}-\mathbf{3}$ and $\mathbf{O}-\mathbf{5}$ were prepared by mixing the same volume of the corresponding $100 \%$ SOC solution with the $0 \%$ SOC solution of the same concentration. The $100 \%$ SOC solutions of $\mathbf{O}-\mathbf{1}, \mathbf{O}-\mathbf{3}$ and $\mathbf{O}-\mathbf{5}$ were obtained by charging them against the aforementioned V(III) solution. By applying an anion exchange membrane (FAPQ-350, Fumatech $\mathrm{GmbH}$, Bietigheim-Bissingen, Germany), the crossover of vanadium species could be avoided, ensuring the purity of the obtained solution. The $0 \%$ SOC solutions of $\mathbf{O}-\mathbf{1}, \mathbf{O}-\mathbf{3}$ and $\mathbf{O}-\mathbf{5}$ were made from dissolving a certain amount of solid in $1 \mathrm{M} \mathrm{H}_{2} \mathrm{SO}_{4}$ or $\mathrm{H}_{3} \mathrm{PO}_{4}$. The cells were charged at an appropriate current (20 to $50 \mathrm{~mA}$, depending on theoretical capacity and cell resistance) to the cut-off voltage of $1.3 \mathrm{~V}$, marking the achievement of full capacity, i.e., $100 \%$ SOC solution was successfully obtained. 


\subsection{Symmetric Cell Cycling Tests}

Symmetric cell testing was first introduced in 2013 to reduce crossover [41]. It was later demonstrated by Milshtein et al. as a method to study the capacity fade of a single electrolyte [42,43]. In 2018, Goulet et al. developed this method further by defining the capacity limiting side (CLS), linking the capacity fade of the cell directly to the stability of the investigated molecule [33]. It soon became a validated and efficient tool to screen new redox active species for their potential application in redox flow batteries. Starting from the 50\% SOC electrolyte solutions on both sides of the cell, the capacity decay caused by crossover due to the poor ion selectivity of membranes could be largely neglected. The concept of 'unbalanced' was introduced to specify the capacity-limiting side and non-capacity-limiting side, making sure that the capacity decay was directly related to the capacity limiting side as a result of decomposition of the redox-active species. All the symmetric cell tests in this work employed anion exchange membrane FAPQ-350 (Fumatech $\mathrm{GmbH}$ ) as the separator because the investigated hydroquinones were positively charged in acidic solution. The cell setup was connected to a peristatic pump (Heidolph pumpdrive 5101) with a flow rate of $16 \mathrm{~mL} \cdot \mathrm{min}^{-1}$. The prepared $50 \% \mathrm{SOC}$ solution was put on both reservoirs with a volume difference of $1 \sim 2 \mathrm{~mL}$. The cathode side was taken as the non-capacity-limiting side (NCLS) and the anode side as the capacity-limiting side (CLS). The charge/discharge program refers to the literature $[8,30,33]$ with necessary modifications on the conditions. The symmetric cells of $\mathbf{O}-\mathbf{1}, \mathbf{O}-\mathbf{3}$ and $\mathbf{O}-\mathbf{5}$ were investigated using both the potentiostatic (PS) cycling method and the galvanostatic (GS) cycling method. In the PS cycling, the charge-discharge voltage was set at $0.3 /-0.3 \mathrm{~V}$ and the cutoff current was $3 /-3 \mathrm{~mA}$, with ten seconds rest when switching between charge and discharge (Figure 6a). In the GS cycling, the cutoff voltage was set at $0.3 /-0.3 \mathrm{~V}$. Current varied according to the theoretical capacity and measured cell resistance (Table A1 in Appendix A).
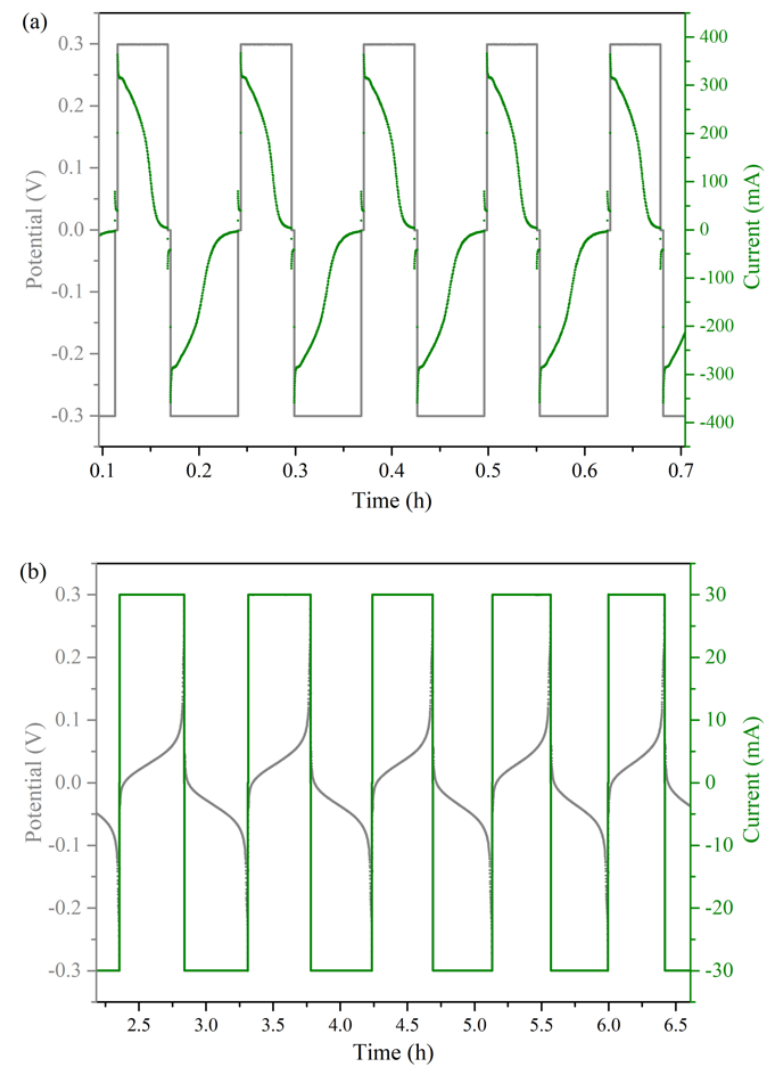

Figure 6. Examples of (a) the PS cycling method and (b) the GS cycling method. 


\section{Conclusions}

A series of four hydroquinone derivatives substituted with morpholinomethylene and/or methyl groups were successfully synthesized via a one-step Mannich reaction. All structures were subsequently confirmed by ${ }^{1} \mathrm{H}$ NMR, ${ }^{13} \mathrm{C}$ NMR, HPLC and MS. The rapid synthesis promises easy scale-up and hence good competitiveness for lowering the cost of RFB systems in practical applications. The stability of the four molecules (O-1, O-3, O-5 and asym-O-5) was evaluated by symmetric flow cell cycling tests in different supporting electrolytes, employing both the potentiostatic (PS) and galvanostatic (GS) cycling methods. Regardless of the supporting electrolytes applied, asym-O-5, with all four ortho positions centrally and asymmetrically substituted by morpholinomethylene and methyl groups, was the most stable among the four molecules, the stability of which was 0.42 to $1.8 \%$ /day. $\mathbf{O}-5$, which had exactly the same chemical composition as asym-O-5 but with molecular central symmetry, exhibited similar stability of 0.78 to $1.1 \%$ /day. However, O-5 was not suitable for long-term application because its solubility in $\mathrm{H}_{2} \mathrm{SO}_{4}$ changed gradually due to the formation of more-stable but less-soluble polymorphs. $\mathbf{O}-\mathbf{1}$, which was also fully substituted with morpholinomethylene and three methyl groups, ranked the third in stability (2.9 7.3\%/day). Results showed that the hydroquinone (O-3) without two unoccupied protons was highly unstable in $1 \mathrm{M} \mathrm{H}_{3} \mathrm{PO}_{4}$ and displayed a capacity decay rate of 48.5 to $52.7 \%$ / day. This fast capacity fade stemmed from decomposition reactions forming insoluble 2,5-dioxoterephthalic acid. Clearly, protecting all ortho position of quinone derivatives is essential for introducing a chemically stable compound as the catholyte in ORFBs. The differences in stability of the three fully substituted hydroquinones provokes the need to study how different substitution patterns can affect molecular stability, thereby providing a future guide for molecular design targeting high stability.

Although the three fully substituted hydroquinones represent difference in cycling stability, they are all well capable of accessing high shares of theoretical capacity ( 82 to $97 \%$ ), significantly higher than AQDS derivatives. Further investigations on the dimerization behavior of this series of hydroquinones will certainly provide valuable insight to realize two-electron transfer at higher concentrations. As compared to reported redox-active organic molecules, asym-O-5 is a good candidate for flow batteries.

Author Contributions: Conceptualization, X.Y. and S.N.G.; methodology, X.Y.; validation, X.Y. and S.N.G.; formal analysis, X.Y. and S.N.G.; investigation, X.Y.; resources, X.Y. and S.N.G.; data curation, X.Y.; writing-original draft preparation, X.Y., S.N.G. and D.K.; writing-review and editing, T.J., D.K., M.D.H. and U.S.S.; visualization, X.Y.; supervision, T.J., D.K., M.D.H. and U.S.S.; project administration, T.J. and D.K.; funding acquisition, T.J., D.K., M.D.H. and U.S.S. All authors have read and agreed to the published version of the manuscript.

Funding: This research was funded by the European Union's Horizon 2020 research and innovation program under Marie Skłodowska-Curie Grant Agreement No. 765289.

Institutional Review Board Statement: Not applicable.

Informed Consent Statement: Not applicable.

Data Availability Statement: The data presented in this study are available on request from the corresponding author.

Conflicts of Interest: The authors declare no conflict of interest.

Sample Availability: Samples of the compounds 0-1, O-3, O-5 and asym-O-5 are available from the authors. 


\section{Appendix A}
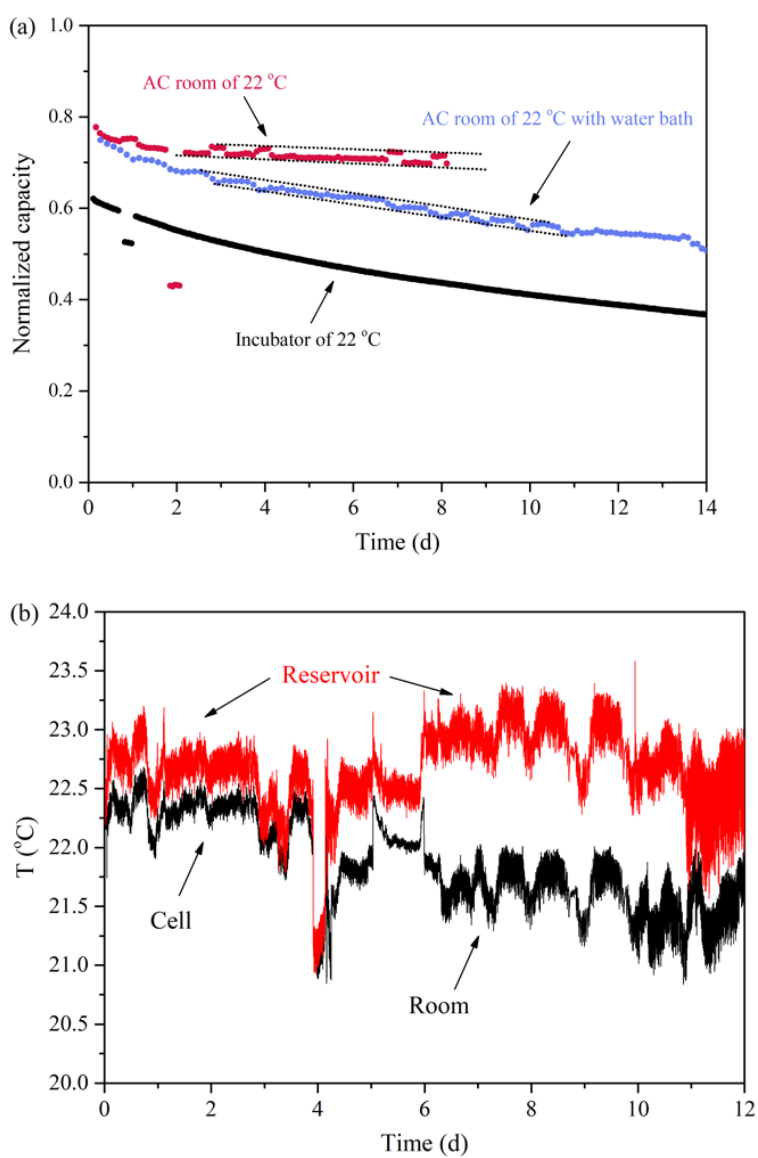

Figure A1. (a) Discharge capacity of a symmetric flow cell using the GS cycling method under different temperature control conditions; (b) temperature of the air-conditioned (AC) room, the cell setup and the electrolyte reservoir.

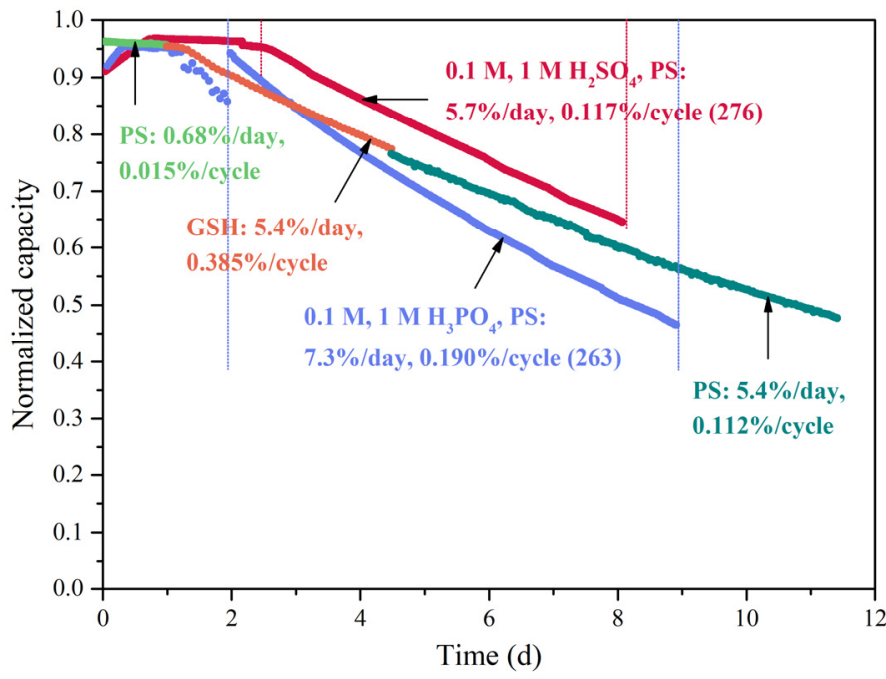

Figure A2. Capacity decay rate of O-1 in different supporting electrolytes $\left(\mathrm{H}_{3} \mathrm{PO}_{4}\right.$ or $\left.\mathrm{H}_{2} \mathrm{SO}_{4}\right)$, using PS and GSH (galvanostatic with potential hold) cycling methods. 
Table A1. Condition, charge/discharge current and cell resistance of the symmetric cell cycling tests using the GS cycling method.

\begin{tabular}{ccc}
\hline Condition & Current (mA) & Cell Resistance $(\Omega)$ \\
\hline $19 \mathrm{~mL} \mathrm{0.05} \mathrm{M} \mathrm{O-1} \mathrm{in} 1 \mathrm{M} \mathrm{H}_{2} \mathrm{SO}_{4}$ & 50 & $0.135 / 0.120$ \\
$9 \mathrm{~mL} \mathrm{0.1} \mathrm{M} \mathrm{O-3} \mathrm{in} 1 \mathrm{M} \mathrm{H}_{3} \mathrm{PO}_{4}$ & 30 & $0.456 / 0.357$ \\
$7 \mathrm{~mL} 0.075 \mathrm{M} \mathrm{O}-5$ in $1 \mathrm{M} \mathrm{H}_{2} \mathrm{SO}_{4}$ & 20 & $0.169 / 0.160$ \\
$9 \mathrm{~mL} 0.1 \mathrm{M}$ asym-O-5 in $1 \mathrm{M} \mathrm{H}_{2} \mathrm{SO}_{4}$ & 20 & $0.134 / 0.122$ \\
\hline
\end{tabular}

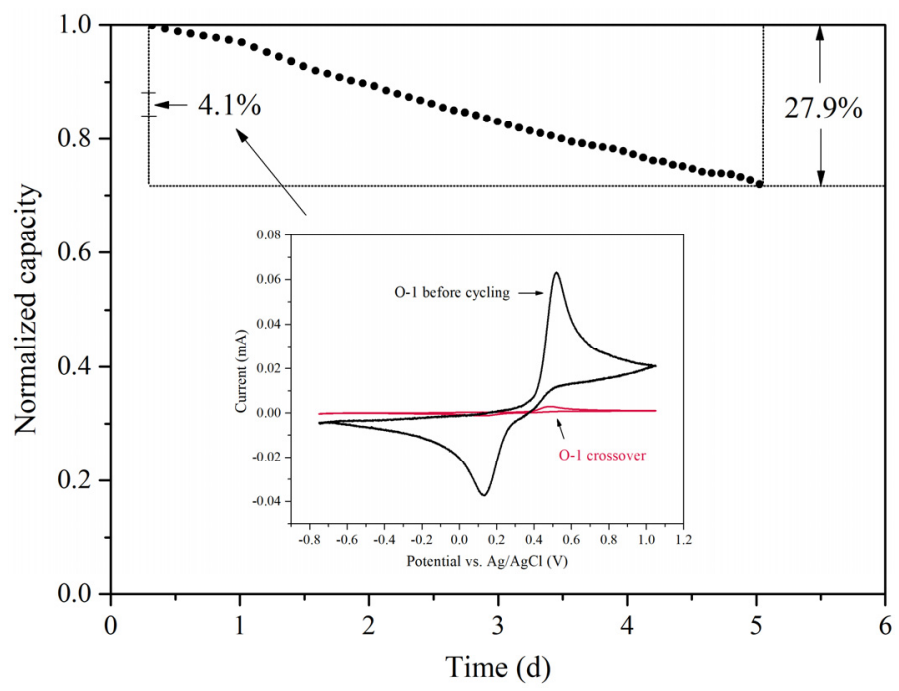

Figure A3. Discharge capacity fade over time. The cell employed $0.5 \mathrm{M} \mathrm{O}-1$ in $1 \mathrm{M} \mathrm{H}_{2} \mathrm{SO}_{4}$ as the catholyte and 1.6 M V(III) as the anolyte. Charge/discharge current was set at $200 \mathrm{~mA}$. The inserted figure is the cyclic voltammogram of $\mathbf{O - 1}$ before cycling and its crossover to the anode side after cycling.

\section{References}

1. Winsberg, J.; Hagemann, T.; Janoschka, T.; Hager, M.D.; Schubert, U.S. Redox-Flow Batteries: From Metals to Organic RedoxActive Materials. Angew. Chem. Int. Ed. 2017, 56, 686-711. [CrossRef]

2. Wang, W.; Sprenkle, V. Energy storage: Redox flow batteries go organic. Nat. Chem. 2016, 8, 204-206. [CrossRef]

3. Xu, Y.; Wen, Y.-H.; Cheng, J.; Cao, G.-P.; Yang, Y.-S. A study of tiron in aqueous solutions for redox flow battery application. Electrochim. Acta 2010, 55, 715-720. [CrossRef]

4. Wedege, K.; Drazevic, E.; Konya, D.; Bentien, A. Organic Redox Species in Aqueous Flow Batteries: Redox Potentials, Chemical Stability and Solubility. Sci. Rep. 2016, 6, 39101. [CrossRef]

5. Wei, X.; Pan, W.; Duan, W.; Hollas, A.; Yang, Z.; Li, B.; Nie, Z.; Liu, J.; Reed, D.; Wang, W.; et al. Materials and Systems for Organic Redox Flow Batteries: Status and Challenges. ACS Energy Lett. 2017, 2, 2187-2204. [CrossRef]

6. Janoschka, T.; Friebe, C.; Hager, M.D.; Martin, N.; Schubert, U.S. An Approach Toward Replacing Vanadium: A Single Organic Molecule for the Anode and Cathode of an Aqueous Redox-Flow Battery. ChemistryOpen 2017, 6, 216-220. [CrossRef] [PubMed]

7. Hagemann, T.; Winsberg, J.; Grube, M.; Nischang, I.; Janoschka, T.; Martin, N.; Hager, M.D.; Schubert, U.S. An aqueous all-organic redox-flow battery employing a (2,2,6,6-tetramethylpiperidin-1-yl)oxyl-containing polymer as catholyte and dimethyl viologen dichloride as anolyte. J. Power Sources 2018, 378, 546-554. [CrossRef]

8. Hagemann, T.; Strumpf, M.; Schröter, E.; Stolze, C.; Grube, M.; Nischang, I.; Hager, M.D.; Schubert, U.S. (2,2,6,6Tetramethylpiperidin-1-yl)oxyl-Containing Zwitterionic Polymer as Catholyte Species for High-Capacity Aqueous Polymer Redox Flow Batteries. Chem. Mater. 2019, 31, 7987-7999. [CrossRef]

9. Janoschka, T.; Martin, N.; Martin, U.; Friebe, C.; Morgenstern, S.; Hiller, H.; Hager, M.D.; Schubert, U.S. An aqueous, polymerbased redox-flow battery using non-corrosive, safe, and low-cost materials. Nature 2015, 527, 78-81. [CrossRef]

10. Khataee, A.; Dražević, E.; Catalano, J.; Bentien, A. Performance Optimization of Differential pH Quinone-Bromide Redox Flow Battery. J. Electrochem. Soc. 2018, 165, A3918-A3924. [CrossRef] 
11. Lee, W.; Permatasari, A.; Kwon, B.W.; Kwon, Y. Performance evaluation of aqueous organic redox flow battery using anthraquinone-2,7-disulfonic acid disodium salt and potassium iodide redox couple. Chem. Eng. J. 2019, 358, 1438-1445. [CrossRef]

12. Leung, P.; Shah, A.A.; Sanz, L.; Flox, C.; Morante, J.R.; Xu, Q.; Mohamed, M.R.; Ponce de León, C.; Walsh, F.C. Recent developments in organic redox flow batteries: A critical review. J. Power Sources 2017, 360, 243-283. [CrossRef]

13. Lin, K.; Chen, Q.; Gerhardt, M.R.; Tong, L.; Kim, S.B.; Eisenach, L.; Valle, A.W.; Hardee, D.; Gordon, R.G.; Aziz, M.J.; et al. Alkaline quinone flow battery. Science 2015, 349, 1529-1532. [CrossRef] [PubMed]

14. Janoschka, T.; Martin, N.; Hager, M.D.; Schubert, U.S. An Aqueous Redox-Flow Battery with High Capacity and Power: The TEMPTMA/MV System. Angew. Chem. Int. Ed. 2016, 55, 14427-14430. [CrossRef]

15. Luca, O.R.; Gustafson, J.L.; Maddox, S.M.; Fenwick, A.Q.; Smith, D.C. Catalysis by electrons and holes: Formal potential scales and preparative organic electrochemistry. Org. Chem. Front. 2015, 2, 823-848. [CrossRef]

16. Gong, K.; Fang, Q.; Gu, S.; Li, S.F.Y.; Yan, Y. Nonaqueous redox-flow batteries: Organic solvents, supporting electrolytes, and redox pairs. Energy Environ. Sci. 2015, 8, 3515-3530. [CrossRef]

17. Hu, B.; DeBruler, C.; Rhodes, Z.; Liu, T.L. Long-Cycling Aqueous Organic Redox Flow Battery (AORFB) toward Sustainable and Safe Energy Storage. J. Am. Chem. Soc. 2017, 139, 1207-1214. [CrossRef]

18. Reichardt, C.; Welton, T. Solvents and Solvent Effects in Organic Chemistry; John Wiley \& Sons: Weinheim, Germany, 2011.

19. Kucharyson, J.F.; Cheng, L.; Tung, S.O.; Curtiss, L.A.; Thompson, L.T. Predicting the potentials, solubilities and stabilities of metal-acetylacetonates for non-aqueous redox flow batteries using density functional theory calculations. J. Mater. Chem. A 2017, 5, 13700-13709. [CrossRef]

20. Cheng, L.; Assary, R.S.; Qu, X.; Jain, A.; Ong, S.P.; Rajput, N.N.; Persson, K.; Curtiss, L.A. Accelerating Electrolyte Discovery for Energy Storage with High-Throughput Screening. J. Phys. Chem. Lett. 2015, 6, 283-291. [CrossRef] [PubMed]

21. Er, S.; Suh, C.; Marshak, M.P.; Aspuru-Guzik, A. Computational design of molecules for an all-quinone redox flow battery. Chem. Sci. 2015, 6, 885-893. [CrossRef]

22. Bachman, J.E.; Curtiss, L.A.; Assary, R.S. Investigation of the redox chemistry of anthraquinone derivatives using density functional theory. J. Phys. Chem. A 2014, 118, 8852-8860. [CrossRef]

23. Huskinson, B.; Marshak, M.P.; Suh, C.; Er, S.; Gerhardt, M.R.; Galvin, C.J.; Chen, X.; Aspuru-Guzik, A.; Gordon, R.G.; Aziz, M.J. A metal-free organic-inorganic aqueous flow battery. Nature 2014, 505, 195-198. [CrossRef] [PubMed]

24. Carney, T.J.; Collins, S.J.; Moore, J.S.; Brushett, F.R. Concentration-Dependent Dimerization of Anthraquinone Disulfonic Acid and Its Impact on Charge Storage. Chem. Mater 2017, 29, 4801-4810. [CrossRef]

25. Wiberg, C.; Carney, T.J.; Brushett, F.; Ahlberg, E.; Wang, E. Dimerization of 9,10-anthraquinone-2,7-Disulfonic acid (AQDS). Electrochim. Acta 2019, 317, 478-485. [CrossRef]

26. Ding, Y.; Li, Y.; Yu, G. Exploring Bio-inspired Quinone-Based Organic Redox Flow Batteries: A Combined Experimental and Computational Study. Chemistry 2016, 1, 790-801. [CrossRef]

27. Yang, B.; Hoober-Burkhardt, L.; Wang, F.; Surya Prakash, G.K.; Narayanan, S.R. An Inexpensive Aqueous Flow Battery for Large-Scale Electrical Energy Storage Based on Water-Soluble Organic Redox Couples. J. Electrochem. Soc. 2014, 161, A1371-A1380. [CrossRef]

28. Hoober-Burkhardt, L.; Krishnamoorthy, S.; Yang, B.; Murali, A.; Nirmalchandar, A.; Prakash, G.K.S.; Narayanan, S.R. A New Michael-Reaction-Resistant Benzoquinone for Aqueous Organic Redox Flow Batteries. J. Electrochem. Soc. 2017, 164, A600-A607. [CrossRef]

29. Tabor, D.P.; Gómez-Bombarelli, R.; Tong, L.; Gordon, R.G.; Aziz, M.J.; Aspuru-Guzik, A. Mapping the frontiers of quinone stability in aqueous media: Implications for organic aqueous redox flow batteries. J. Mater. Chem. A 2019, 7, 12833-12841. [CrossRef]

30. Drazevic, E.; Szabo, C.; Konya, D.; Lund, T.; Wedege, K.; Bentien, A. Investigation of Tetramorpholinohydroquinone as a Potential Catholyte in a Flow Battery. ACS Appl. Energy Mater. 2019, 2, 4745-4754. [CrossRef]

31. Garcia, S.N.; Yang, X.; Bereczki, L.; Konya, D. Aqueous Solubility of Organic Compounds for Flow Battery Applications: Symmetry and Counter Ion Design to Avoid Low-Solubility Polymorphs. Molecules 2021, 26, 1203. [CrossRef]

32. Ma, L.; Wang, Z.; Li, Q. Study on electrochemical oxidation behaviors and the diffusion mechanism of hydroquinone at pre-anodized carbon paste electrode by cyclic voltammetry. Analyst 2012, 137, 432-436. [CrossRef]

33. Goulet, M.-A.; Aziz, M.J. Flow Battery Molecular Reactant Stability Determined by Symmetric Cell Cycling Methods. J. Electrochem. Soc. 2018, 165, A1466-A1477. [CrossRef]

34. Kwabi, D.G.; Ji, Y.; Aziz, M.J. Electrolyte Lifetime in Aqueous Organic Redox Flow Batteries: A Critical Review. Chem. Rev. 2020, 120, 6467-6489. [CrossRef]

35. Beh, E.S.; De Porcellinis, D.; Gracia, R.L.; Xia, K.T.; Gordon, R.G.; Aziz, M.J. A Neutral pH Aqueous Organic-Organometallic Redox Flow Battery with Extremely High Capacity Retention. ACS Energy Lett. 2017, 2, 639-644. [CrossRef]

36. Broadbent, A.D.; Melanson, R.J. The Redox Behavior of 9,10-Anthraquinone-2-sulfonate in Acidic Aqueous Solution. Can. J. Chem. 1975, 53, 3757-3760. [CrossRef]

37. Li, W.; Fu, H.C.; Li, L.; Caban-Acevedo, M.; He, J.H.; Jin, S. Integrated Photoelectrochemical Solar Energy Conversion and Organic Redox Flow Battery Devices. Angew. Chem. Int. Ed. 2016, 55, 13104-13108. [CrossRef] [PubMed] 
38. Zhang, S.; Li, X.; Chu, D. An Organic Electroactive Material for Flow Batteries. Electrochim. Acta 2016, 190, 737-743. [CrossRef]

39. Cao, J.; Zhu, Z.; Xu, J.; Tao, M.; Chen, Z. Nitrogen-doped porous graphene as a highly efficient cathodic electrocatalyst for aqueous organic redox flow battery application. J. Mater. Chem. A 2017, 5, 7944-7951. [CrossRef]

40. Yang, Z.; Tong, L.; Tabor, D.P.; Beh, E.S.; Goulet, M.-A.; De Porcellinis, D.; Aspuru-Guzik, A.; Gordon, R.G.; Aziz, M.J. Alkaline Benzoquinone Aqueous Flow Battery for Large-Scale Storage of Electrical Energy. Adv. Energy Mater. 2018, 8, 1702056. [CrossRef]

41. Darling, R.M.; Perry, M.L. Half-Cell, Steady-State Flow-Battery Experiments. ECS Trans. 2013, 53, 31-38. [CrossRef]

42. Milshtein, J.D.; Barton, J.L.; Darling, R.M.; Brushett, F.R. 4-acetamido-2,2,6,6-tetramethylpiperidine-1-oxyl as a model organic redox active compound for nonaqueous flow batteries. J. Power Sources 2016, 327, 151-159. [CrossRef]

43. Milshtein, J.D.; Kaur, A.P.; Casselman, M.D.; Kowalski, J.A.; Modekrutti, S.; Zhang, P.L.; Harsha Attanayake, N.; Elliott, C.F.; Parkin, S.R.; Risko, C.; et al. High current density, long duration cycling of soluble organic active species for non-aqueous redox flow batteries. Energy Environ. Sci. 2016, 9, 3531-3543. [CrossRef] 